\title{
Bilim Tarihi Disiplini ve Bilim Tarihine Farklı Yaklaşımlar
}

\author{
Yavuz Unat ${ }^{1^{*}}$ \\ 1Kastamonu Üniversitesi, Fen-Edebiyat Fakültesi, Felsefe Bölümü, Kastamonu, Türkiye \\ ORCID: Yavuz Unat (0000-0002-2561-6341)
}

\begin{abstract}
Özet: Bilim tarihi, bilginin hangi aşamalardan geçerek bugün bilim dediğimiz bilgi türünün oluştuğunu, bilime ne gibi ve ne zamanlar katkılar yapıldığını konu edinen bir disiplindir. Bilim tarihi bu süreçte özellikle şu noktalara dikkatini yoğunlaştırmaktadır: Bilginin aşamalarını belirlemek, bilimsel kuramların doğuşunu ve gelişimini olgusal ve deneysel verilere dayanarak betimlemek, bir toplumun bilime ne zaman ve hangi durumlarda katkı yapabildiğini örneklerle ortaya koymak, bu katkılar yapılırken bilim adamlarının nasıl bir uğraş verdiklerini, kullandıkları yöntemleri, araç ve gereçleri göz önüne sermek, bilimin değerini ve önemini sorgulayarak, bilimsel etkinliği bütün yönleriyle tanımaya ve tanıtmaya çalışmak, elde edilen bilimsel sonuçların uygulamaya nasıl geçirildiklerini, bunların insan yaşamında ne gibi değişikliklere neden olduğunu incelemek, bir toplumun bilime katkı yapacak düzeye getirilebilmesi için neler yapılması gerektiğini somut örneklere dayanarak göstermek. Bu makalemizde bilim tarihi disiplinin dünyada ve Türkiye'deki gelişimi üzerinde durulacak ve bilim tarihi üzerine yöntemler tartışılacaktır.
\end{abstract}

Anahtar Kelimeler: Bilim Tarihi, Bilim Tarihinde Yöntem

\section{Discipline of the History of Science and Different Approaches to the History of Science}

\begin{abstract}
The history of science is a discipline that acquires the subject of what stages of knowledge we call science today, through which the type of knowledge is formed, what and when contributions were made to science. In this process, the history of Science focuses on issues such as the stages of development of knowledge, the birth and development of scientific theories, the value and importance of Science, and its impact on human and social life. In this article, we will focus on the development of the discipline of the history of Science in the world and in Turkey, and methods on the history of science will be discussed.
\end{abstract}

Key world: The History of Science, The Methods of History of Science

"Bilim tarihi, hurafe ve cahilliğin ataletine, yalancılara ve ikiyüzlülere, başkalarını ve kendilerini aldatanlara, karanlı̆̆ın ve zırvalı̆̆ın gücüne karşı hiç bitmeyecek olan planlı bir mücadelenin tarihidir."

George Sarton (1962)

\section{BILIM TARIHI DISIPLININ ORTAYA ÇIKIŞI}

Bilim tarihi, ilerlemeci bakış açısının bir parçası olarak, ilerlemeyi sağlam bir biçimde bilimsel başarılara dayalı hale getirerek kalıcı, programlı, yönlü ve yöntemli bir süreç haline getirmek amacıyla, entelektüel açıdan epeyce yol almış ülkelerin hayata geçirdiği bir entelektüel kalkınma programıdır. Programın düşünsel altyapısını Aydınlanma düşünce hareketinin de alt yapısını oluşturan bilim ve felsefeye güven ve bağlanma oluşturmaktadır (Topdemir \& Unat, 2020, s. 227).

Bilim tarihi alanının ortaya çıkışında iki önemli geliş-

*Yazışma Adresi / Address for Correspondence:

Y.Unat, Email: yavuzunat@hotmail.com

Geliş Tarihi / Received Date: 14.07 .2021

Kabul Tarihi / Accepted Date: 21.08.2021

Doi: 10.32329/uad.971531 menin etkili olduğu görülmektedir: 1) 16. yüzyıldan sonra bilimsel bilgi birikiminin artmasıyla bilimler büyük bir hızla gelişmiş ve 18. yüzyılın başlarından itibaren insanoğlunun yaşantısını büyük bir ölçüde değiştirmeye başlamıştır. Böylece, bilimsel etkinliğin doğru bir biçimde anlaşılabilmesi ve bilimsel süreçlerin daha yakından tanınabilmesi için bilim tarihine olan gereksinim artmıștır. 2) Aydınlanma Çağı olarak adlandırılan 18. yüzyılda, akla büyük bir değer verilmiş ve tarih, insan aklının gelişim evrelerini anlamaya çalışan bir etkinlik veya bir soruşturma olarak görülmüștür. Bu yaklaşımı benimseyen düşünürlere göre, bilim üreten akıl en gelişmiş akıldır ve bu aklın niteliklerinin kavranabilmesi için, bilim öncesi dönemle bilim sonrası dönemi karşılaştıracak bir tarih alanına gereksinim vardır ve bu alan da bilim tarihi olmalıdır.

Bilim tarihini akademik bir disiplin hüviyetini, Auguste Comte (1798-1857), Paul Tannery (1843-1904), Henri Poincaré (1854-1912) ve Pierre Duhem (1861-1916) gibi bilim tarihçilerinin ve bilim felsefecilerinin etkisi ile bilim tarihi araştırmalarına yönelmiş olan George Sarton'ın (1884-1956) 1936 yılında Harvard Üniversitesi'nde bilim tarihi doktora programını kurmasıyla kazanmıștır. Sarton'a göre bilim tarihi bir keșifler hikâyesi değildir; keșifler geçicidir. Bir süre sonra eski keșiflerin yerini yenileri 
alır. Bir bilim tarihçisinin asıl görevi keşifleri kaydetmek değil, bilimsel düşüncenin gelişimini, yani insan bilincinin gelişimini açıklamaktır (Unat, 2005). Pozitivist bir bakış açısını sergileyen bu görüş, bilim tarihi tezi ve disiplininin kurulmasında etkili oldu ve Sarton'dan sonra bilim tarihi, insanı ve insan aklının gelişimini anlamanın en önemli araçlarından biri olarak görüldü.

Sarton'a göre bilim uygarlığa ilerlemeci karakterini kazandırdığı gibi insanlık üzerinde birleștiği bir etkinliktir. $\mathrm{Bu}$ etkinliğin tam ve eksiksiz olarak kavranması ise ancak bilim tarihi disipliniyle olanaklıdır. Bilim tarihi ayrıca epistemolojik açıdan oluşan sorunlara ve bilimle ilgili tartışma yaratan diğer pek çok soruna yeni bir bakış açısı kazandırabilir (Sayılı, 1996, s. 118). Sarton, bilim tarihi çalışmalarının ne denli önemli olduğuna dikkat çekmek için de bilim tarihini yeni hümanizma (Sarton, 1924, s. 9; 10-11) olarak adlandırmıştır. Bu düşüncesinin dayanağı da Bilim Tarihine Giriş başlıklı üç ciltlik kapsamlı çalışmasında ele alır. Bu çalışma, bilimin hiçbir toplumun tekelinde bulunmadığının, her toplumun gelişmişlik düzeyine koşut olarak bilime katkıda bulunduğunun, hiçbir toplumun tek başına bilimsel gelişmenin mimarı ve sürdürücüsü olmadığının açıkça anlaşılmasını sağlamıştır (Topdemir \& Unat, 2020, s. 229).

\section{TÜRKIYE'DE BILIM TARIHI}

Türkiye'de akademik anlamda beş önemli merkezde bilim tarihi çalışmaları sürdürülmektedir. Bunlardan ilki ve en eskisi Ankara Üniversitesi, Dil ve Tarih Coğrafya Fakültesi'nde 1955 yılında Ord. Prof. Dr. Aydın Sayılı tarafindan kuruldu. 1984 yılında Prof. Dr. Ekmeleddin İhsanoğlu tarafından İstanbul Üniversitesi Edebiyat Fakültesi Felsefe Bölümü'nde ikinci bir Bilim Tarihi kürsüsü açıldı. Bu kürsü 1989 yılında bölüm haline getirildi. 2000 yılında YÖK tarafından anabilim dalına çevrilmesine karşın, 2009 yılında yine YÖK'ün aldığı kararla tekrar bölüm olarak faaliyetlerine devam etti. 2009 yılında Kastamonu Üniversitesi’nde bir Bilim Tarihi Bölümü kuruldu. Ancak bu üniversitede bilim tarihi faaliyetleri henüz felsefe bölümü içerisinde yer almaktadır. 2013-2014 eğitim - öğretim yılında Fatih Sultan Mehmet Vakıf Üniversitesi Edebiyat Fakültesi'nde bir bilim tarihi bölümü açıldı ve bu tarihten sonra da İstanbul Medeniyet Üniversitesi Edebiyat Fakültesi'nde bir bilim tarihi bölümü kuruldu.

Türkiye'de bilim tarihi araştırmalarında, 1989 tarihinde Türk Bilim Tarihi Kurumu'nun kurulması ile kurumsallaşma yolunda önemli bir adım atılmış, böylece bu alanda çalışan araştırmacıların bir araya toplanması sağlanmiştır (Kaçar, 2004).

\section{TÜRK BILIM TARIHI YAZICILIĞININ ÖNCÜLERI}

Türk bilim tarihi yazıcılığ başladığını söylemek yanlış olmaz. Âsâr-ı Bâkiye (İstan- bul, 1911) bu alanda en önemli eseridir. Salih Zeki Bey, bu eserini matematiğin her dalına dair muhtelif zamanlarda yazılmış olan temel yapitları esas kabul ederek, Doğulu bilginlerin Eski Yunan matematiği üzerine neler ilave ettiklerini ve bunları, Batılılara ne düzeyde teslim ettiklerini bildirmek amacıyla kaleme almıştır. İçerik ve yöntem açısından bilim tarihine ilişkin ilk önemli eserdir. Dört cilt olarak tasarlanmış maalesef iki cildi basılabilmiştir.

Adnan Adıvar (1882-1955) Türkiye'de bilim tarihi araştırmalarının tanınması ve sevilmesinde öncüdür. Paris'te Ecole des Langues Orientales Vivantes'de hocalık yapmış (1929-1939) ve bu sırada La Science chez les Turcs Ottomans (Paris, 1936) adlı eserini kaleme almıștır. 1940 yılında bu eseri geliştirerek İstanbul'da Osmanlı Türklerinde İlim adıyla yeniden basmıştır. Eser Osmanlıların bilimsel faaliyetlerini ana çizgileriyle tanıtan bir başvuru kaynağıdır (Kâhya, Gökdoğan, Demir, Topdemir, \& Unat, 2003).

Türk bilim tarihçiliği Sayılı’nın (1913-1993) Dil ve Tarih-Coğrafya Fakültesi'nde açtığı kürsüyle kurumsallaşmış ve akademik olarak faaliyetlerini sürdürmeye başlamıştır. Sayılı’nın Türk bilim tarihçiliğine yaptığı en önemli katkı Ortaçağ İslam Dünyası́nda Müslümanlar ve özellikle Türkler tarafından kaleme alınan bilimsel yapıtlara yönelik araştırmaları sistematik bir biçimde başlatmış olmasıdır. Sayılı, Harvard'da bu alanın akademik anlamda kurucusu kabul edilen George Sarton'un yanında doktorasını tamamladı ve bu alanda ilk doktora yapma imkânına erişti (1942). Sayılı'nın doktora tezi Institution of Science and learning in the Muslim World (İslam Dünyasında Bilim ve Eğitim Kurumları) adını taşımaktadır. Türkiye'ye döndükten sonra ise Amerika'da çalıștığı İslam Dönemi gözlemevleri konusuna ilişkin olarak The Observatory in Islam (İslam Dünyası'nda Gözlemevleri, Ankara 1960) adlı eserini yayımladı. Burada temel tezi gözlemevlerinin bir kurum olarak ilk defa İslam Dünyası'nda kurulduğudur (Unat, 2015).

Tıp tarihçimiz Prof. Dr. Aykut Kazancıgil, Ord. Prof. Dr. Aydın Sayılı'nın mesleki alandaki hizmetinin üç temel özelliğini şöyle belirtmektedir: 1. Sayılı, memleketimizde Bilim Tarihi'ni meslek olarak seçen ve bu konuda doktora yapan ilk kişidir. 2. Uzun yıllar Ankara Üniversitesi, Dil Tarih-Coğrafya Fakültesi'nde öğretim üyesi olarak çalışmış, bilim tarihi dalında geniş bir kadro yetiştirmiştir. 3. Yayınları ile Türk Bilim Tarihini dünyaya tanıtmıştır (Kazancigil, 1993, s. 20-26).

Sayılı Türkiye'de akademik anlamda Bilim Tarihi’nin kurucusudur. Daha öncesinde Sâlih Zeki Bey ile Adnan Adıvar gibi bilginlerin yapmış oldukları çalışmalar sonucunda Türkiye'de bilim tarihi araştırmaları tanınmıştır. Salih Zeki'nin bilim tarihi araştırmalarında ortaya koyduğu tarih perspektifi ve metin incelemesi yöntemine Sayll, medeniyet perspektifi ile tenkitli metin neşrini eklemiş (Fazlığlu, 2004, s. 20) ve böylece tanımlayıc1-anlatımcı tarzdan çok analizci-yorumcu bir tarz geliş- 
tirmiştir (Çalışkan, 2004). Sayılı birçok öğrenci yetiştirdi ve bilim tarihinin gelişimine katkıda bulundu.

Sayılı'nın yanında ilk doktora yapan Prof. Dr. Sevim Tekeli'dir. Tekeli, Nasîrüddîn, Takiyüddîn ve Tycho Brahe'nin Rasat Âletlerinin Mukayesesi başlı̆̆ını taşıyan araştırması ve arkasından 16. yüzyıl bilginlerinden Takiyüddin üzerine yaptığı çalışmalarla, Batı'da basit bir müneccim (astrolog) olarak tanınan Takiyüddin'in aslında dönemin dünyaca ünlü bilim adamı olduğunu kanıtladı (Unat, 2015).

Prof. Dr. Esin Kâhya ise Sayılı tarafından biyoloji tarihine yönlendirildi, Şemseddîn İtâkînin Resimli Anatomi Kita$b \iota$ adlı tezi ile 1971'de doktor oldu. Tıp tarihi üzerine yaptığı çalışmalarla, Türklerin ve Osmanlıların bu alanda ne kadar ileride olduğunu gösterdi (Unat, 2017).

Bilim tarihi yazıcılığında diğer öncü isimler Prof. Dr. Ekmeleddin İhsanoğlu ve Prof. Dr. Fuat Sezgin'dir. 1943 yılında doğan İhsanoğlu, kimya eğitimi almasına karşın bilim tarihine ilgi duydu ve İslâm Tarih, Sanat ve Kültür Araştırma Merkezi’nin genel direktörlüğünün yanı sıra İstanbul Üniversitesi Edebiyat Fakültesi Bilim Tarihi Bölümü ile Türk Bilim Tarihi Kurumu'nun başkanlığı ve İstanbul Üniversitesi Bilim Tarihi Müze ve Dokümantasyon Merkezi müdürlüğü görevlerinde bulundu. Osmanlı Astronomi Literatürü Tarihi, Osmanlı Coğrafya Literatürü Tarihi gibi önemli eserler kaleme alan İhsanoğlu, 2008 yılında uluslararası bilim tarihi ödülü olan Koyre Madalyası'na layık görüldü.

Bilim tarihi çalışmalarını yurtdışında sürdüren ve daha sonra Türkiye'ye gelen Prof. Dr. Fuat Sezgin de bilim tarihinin öncü isimlerindendir. 24 Ekim 1924 yılında Bitlis'te doğan Sezgin, 1943 yılında İstanbul Üniversitesi Arap Dili ve Edebiyatı bölümüne (Şarkiyat Enstitüsü) girdi. Burada meşhur oryantalist Alman Hellmut Ritter'in öğrencisi oldu. Ritter'in tavsiyesi üzerine İslam bilimlerine yönelen Sezgin, 1951'de İstanbul Üniversitesi Edebiyat Fakültesi'ni bitirdikten sonra "Buhari'nin Kaynakları" adlı doktorasını bitirdi ve 1954'te doçent oldu.

1960 darbesiyle birlikte üniversiteden atılan 147 akademisyenden biri olarak Türkiye'yi terk etmek zorunda kalan Sezgin Frankfurt Üniversitesi'nde çalışmalarına devam etti. 1965 yılında Cabir ibn Hayyan konusunda ikinci doktora tezini Frankfurt Üniversitesi'nde sunan Sezgin bir yıl sonra profesör unvanını kazandı ve aynı yıl kendisi gibi şarkiyatçı olan Ursula Sezgin ile evlendi. 1967 yılında bilim tarihinde en kapsamlı eserlerden biri olan Arap-İslam Bilim Tarihi'nin ilk cildini tamamladı; bu eser 2000 yılında 13 cilde ulaştı. Sezgin, 1982 senesinde, J. W. Goethe Üniversitesi'ne bağlı Arap-İslam Bilimleri Tarihi Enstitüsü'nü ve 1983'te de buranın müzesini kurdu. Müzede, Müslüman bilginler tarafından yapılmış aletlerin ve bilimsel araç ve gereçlerin, yazılı kaynaklara dayanarak yaptırılan örnekleri sergilenmektedir.

Arap-İslam Bilimleri Enstitüsü için hazırladığı bilimsel araç ve gereçlerin benzerlerini 25 Mayıs 2008 tarihinde Kültür ve Turizm Bakanlığı'na bağlı İstanbul İslam, Bilim ve Teknoloji Müzesi’nde sergilenmesinde öncülük eden Sezgin 30 Haziran 2018' de hayata gözlerini yumdu (Tekeli, ve diğerleri, 2021, s. 391-392).

\section{BILIM TARIHI EĞITIMI}

Bilim tarihçisinin eğitimi nasıl olmalıdır? Günümüzde bir bilim tarihçisi, bu alanda yetişmek için ikili bir eğitimden geçmektedir. Sarton, bu konuda şunları söyler:

"Bilim tarihçisinin kullandiğı yöntemler, ister istemez diğer tarihçiler tarafindan kullanılan yöntemlere benzer; fakat diğer tarihçiler bilimsel hakikatlere ve kuramlara müracaat ederken, bilim tarihçileri, tamamen tarihsel olduğu kadar bilimsel bir hazırlık döneminden de geçmelidirler. Yeterli bir bilimsel bilgiye sahip olmaksıın bilimsel belgeleri anlamak ve değerlendirmek mümkün değildir. Bilim tarihinin bütün güçlüğ̈̈, çifte e $\breve{g} i-$ tim zorunluluğundan kaynaklanmaktadir." (Sarton, 2020, s. 55).

"Tarihsel yöntemler, fiziksel yöntemlerden genellikle daha az somut ve daha çok narindir ve bu nedenle ayrintılariyla anlatılmasi daha zordur... Eski ve orta dönemleri veya Doğu bilimini araştırmak için gerekli olan yöntemler, şüphesiz, modern hadiseleri açıklamak için ihtiyaç duyulanlardan daha güçtür. Kendi lisanımızla anlatılan çă̆daş olaylar söz konusu olduğunda yeterince iyi bildiğimiz geçmişi incelemek veya dilbilimsel güçlükleri hesaba katmak hemen hemen hiç gerekmez. Diğer taraftan, bir kimse dokuzuncu yüzyılda Bağdat'ta yazılmış Arapça eserlerin ihtiva ettiği trigonometrik hususlarl değerlendirmeye çalışacağı zaman, o yerin ve dönemin kültürünü hatırlayabilmesi, Arap dilini ve İslâm dinini anlayabilmesi vs. gerekir. Bu çalışma türü sadece tarihsel değil, aynı zamanda dilbilimsel bir hüviyete de sahiptir." (Sarton, 2020, s. 56).

Öyleyse, bilim tarihçilerinin çalışmalarını sağlıklı bir şekilde yürütebilmeleri, şu şartları öncelikle yerine getirmelerine bağlıdır:

1. Bir bilim tarihçisi, diğer kültür tarihçileri gibi, metinleri okuyup doğru anlayacak kadar klasik dillerden birini (Arapça, Farsça, Latince, Yunanca, vs.) öğrenmelidir.

2. Bir bilim tarihçisi, yine diğer kültür tarihçileri gibi, tarih bilimini öğrenmeden işe girişmemelidir. Çoğu araştırmacı, tarih biliminin, nasıl bir bilim olduğunu bilmez ve tarihçi olmadan tarih yazmaya başlar. Oysa diğer bilimler gibi tarih biliminin de araştırma yöntemleri vardır ve tarih yazmaya başlamadan önce bunları öğrenmek gerekir. 
Bir bilim tarihçisi hem içinde bulunduğu hem de çalıştığ dönemin bilimsel bilgisini öğrenmelidir; bu gereklilik bilim tarihçilerinin işini inanılmaz ölçüde güçleştirir (Dosay \& Demir, 1995, s. 64; Unat, 2015, s. 76-78).

Bilim tarihçisi tarihi yöntemi kullanır ve kaynakları tarihi malzemeye dayanır. Bu kaynakları karşılaştırmalı olarak inceler ve kaynaklara dayanarak görüş beyan eder. Bilim tarihçisi genel itibariyle konuyu iki esastan ele alır: 1) Yatay ve 2) Dikey. İlkinde çalışmalar daha çok bölgesel veya genel bilim tarihi çalışmaları değerlendirilir. Çin bilim tarihi, klasik dönem bilimsel çalışmaları, Osmanlı bilimi gibi. İkincisinde ise bilimin belli bir dalının gelişimi ele alınır. Fizik, matematik, astronomi, tıp tarihi gibi. Bilim tarihçisi konuları değerlendirirken siyasi olayları, ekonomik faktörleri, dini inançları, dönemin felsefi tartışmalarını da göz önüne almak durumundadır. Bilimsel gelişimin adımları ancak bu şekilde değerlendirilebilir (Kahya, 2009, s. 95-97). Sonuçta bir bilim tarihi çalışması tarih, kültür, felsefe tarihi, dinler tarihi gibi değişik dallardaki bilgiye dayalı bir araştırma alanıdır (Kahya, 2009, s. 100),

\section{BILIM TARIHINE YAKLAŞIMLAR}

Bilim tarihine bakış açısına ilişkin tüm bu tartışmalar aslında bilimin ne olduğuna dair tanımlamalara dayanır. Bilimsel bilgi tek başına yani bilim insanından bağımsız olarak gelişen bir bilgi türü müdür yoksa tarihsel ve kültürel şartlar (hatta sosyoloji şartlar) bilimsel gelişimi etkilemekte midir? Bu soruya verilen yanıtlar çerçevesinde bilim tarihine bakış açısı da değişmektedir. Genel olarak bilimin tarihini incelenmesinde iki farklı anlayış hakimdir: İçselci anlayış ve dişsalcı anlayış. İçselci bilim tarihinde bir bilimsel gelişme ve bu gelişmeyi ortaya koyan bilim insanı, dış bağlamdan bağımsız olarak ele alınmalıdır. Örneğin Alexander Koyre'nin ifadesine göre "Floransa Galiei'yi açıklamaz". Dışsalcı bilim tarihi yaklaşımdan ise bir bilimsel gelişme toplumdan, ekonomiden, ideolojiden, politik bağlamdan soyutlanamaz (Acot, 1999, s. 95).

\section{6. İÇSELCI YAKLAŞIM}

Pozitivist geleneğe göre bilgi kuramsal çekirdeği gereği zorunlu olarak içselcidir. İçselci yaklaşımın karakteristiği, bilimsel araştırmanın geçmişini diğer sosyal fenomenlerden bağımsız bir mekanizma olarak ele almasıdır. İçselcilik bilimsel fikirlerin deviniminin bir iç dinamik tarafından sağlandığını ileri süren anlayıştır (Acot, 1999, s. 52). Buna göre, bilimin tarihi, bilimsel problemlerin ve çözümlerinin tarihidir. Bu problemler ve çözümler bir mekanizma olarak bilimin içsel dinamikleri ve etkileşimi ile açığa çıkarılır ve çözülürler. Standart bir bilim tarihi çalışması öncelikle bilimsel çalışmaların tarihsel olarak tespit edilmeleri ve kronolojik olarak sıralanmalarına dair bir araştırma ile başlar. Bundan sonrasında bilim tarihinin görevi sözü edilen içsel ilişkilerin kurulmasıyla mevcut bilimsel gelişmişlik durumuna kadar gelen bi- limlerin geçmişinin bilimin tarihine dönüştürülmesidir. $\mathrm{Bu}$ araştırma biçimi için iktisadi ve politik tarih konu dışıdır.

İçselci yaklaşım temel olarak pozitivizmden yola çıkar ve bu alanın kurucusu Auguste Comte'un düşünceleri genellikle bu yaklaşımda öncü olmuştur. Comte insanlık tarihinin anlaşılabilmesi için bilim tarihinin incelenmesi gerektiğini vurgulayan öncülerden, hatta bu alanda yap1lan çalışmaların önemini çoğu insandan önce fark eden kişidir (Sarton, 1952, s. 357).

Comte'un bilim tarihine önem addetmesi onun kurmuş olduğu Pozitivizm düşüncesine dayanır. Ona göre insanlık üç önemli aşamadan geçmiştir (Üç Hal Yasası): 1) Fenomenlerin oluşumlarının doğa üstü etkenlerle açıklandığı evre. 2) Fenomenlerin oluşumlarının soyut, metafizik etkenlerle açıklandığı evre. 3) Fenomenlerin oluşumlarının bilimsel olarak açıklandığı evre (Comte, 2015, s. 17-20). Tüm bilimler ona göre bu üç evrenden geçerek şekillenmiştir ki bilimler tarihi de bunu onaylar (Comte, 2015, s. 21).

Comte'a göre bilim tarihi iki temel yöntemle ele alınabilir: 1) Tarihsel yöntem; bu yöntemle bilgiler sırayla ve mümkün olduğunca aynı yolları takip ederek art arda açıklanır. 2) Dogmatik yöntem; bilim kendi bütünlüğünde yeniden ele alınır. Birinci yöntemde kronolojik sırada incelenirken ikinci yöntem yüksek gelişmiş bir bilime uygulanabilir ve o bilimin doğal ve mantıksal bir sırada geliştiğini gösterir. BU düzen aynı zamanda insan aklının gelişimini bize verir. Dolayısıyla insan aklının gelişiminin takibi için bilimlerin tarihinin bilinmesi yüksek bir öneme sahiptir (Comte, 2015, s. 99-102).

Comte'un bu düşünceleri bilim tarihine olan önemi arttırdı. Bilim tarihinin bir disiplinin olarak gelişiminde birçok öncüden söz edilir. Bunların içinde iki bilim insanı öne çıkar. Pierre Duhem ve bu alanın akademik kurucusu George Sarton.

Paris'te doğan Duhem (1861-1916), Collège Stanislas ve Ecole Normale'de öğrenim gördü. Lille'de, sonra Rennes'de ve son olarak Bordeux'da (1894) matematik, fizik ve teorik fizik alanlarında ders verdi. Önce termodinamik ve kimya problemlerine yöneldi. Termodinamik ile Lagrange mekaniğini birleştiren yeni bir teori geliştirmeyi denedi. Eğitimi gereği fiziğin diğer kısımlarıyla da (hidrodinamik, esneklik, elektrik ve manyetizma) ilgilendi ve orijinal görüşler ortaya koydu. Çalışmaları pür bilimden, bilim felsefesine kadar uzanır. Bilim felsefesi, onu kaçınılmaz olarak bilim tarihine yöneltmiştir.

Duhem Ortaçağ bilimsel düşüncesi uzmanıdır. Ortaçağ astronomisi ve fiziği üzerine çalışmıştır. Başlıca tarihsel çalışmaları şunlardır: J. Clerk Maxwell'in Elektrik Teorileri (Les théories électriques de J. Clerk Maxwell, 1902). Mekaniğin Evrimi (L'évolution de la mécaniqueü, 1903). Statiğin Temelleri (Les origines de la statique (2 cilt, 1905-1906). Fiziksel Teori, Nesnesi ve Yapısı (La théorie 
physique, son objet et sa structure, 1906). Leonardo da Vinci Üzerine Çalışmalar (Etudes sur Léonard de Vinci, 3 cilt, 1906, 1909, 1912). Dünya Sistemi (Le système du monde, 12 cilt olarak ilan edildi, ancak 7 veya 9 cildi yazıldı ve sadece 1913-1917 arasında 5 cildi yayımlandı) (Sarton, 2020, s. 115-119).

Bilim tarihi disiplinin akademik kurucusu George Sarton'dır (1884-1956). Sarton'ın bilim tarihi üzerindeki etkisi tartışılmazdır. Bilim tarihi alanında kurduğu dergi (ISIS) ve hepsinin ötesinde klasik Introduction to the History of Science eseri ile bu yeni alanı oluşturmaya ve bu alanın gerekliliklerini belirlemeye yönelik çok önemli girişimlerde bulunmuştur. Harvard'daki varlığı, daha sonra dünya bilim tarihinin önde gelen merkezlerinden biri haline gelmesinde etkili olmuştur.

Sarton'a göre pozitif bilgi bir bütündür ve insanlık tarihinin anahtarıdır. Bilim tarihi insan doğasının karmaşıklığına ilişkin benzersiz bilgiler verir. Sarton'ın amacı Introduction to the History of Science adl eserinde belirtiği gibi;

"Kısaca, ancak mümkün olduğunca tam bir şekilde, insan medeniyetinin asıl evresinin gelişimine... yani bilimin gelişimine... bilimsel ilerlemenin açıklamasına önemli oranda yer vermeyen hiçbir medeniyet tarihi tam olamaz" (Sarton, 1927-1948, s. 3). Aslinda Sarton'a göre; "Bilim tarihi, insanlı̆̆ın ilerlemesini gösteren tek tarihtir. Aslında "ilerlemenin" bilim dişında başka alanlarda kesin ve tartışılmaz bir anlamı yoktur." (Sarton, 1957, s. 5).

Ancak Sarton'ın bilim tarihine verdiği öneme rağmen, disiplin bir amaç değil bir araçtı; nihai hedefi, bilimler ve beşerî bilimler arasındaki boşluğu dolduran bütünleşmiş bir bilim felsefesi, "yeni hümanizm” olarak adlandırdığ bir idealdi. Sarton, bilim adamları ve hümanistler arasındaki fikir ayrılığını "kültürümüzü paramparça hale getiren ve onu mahvetmek konusunda tehdit eden bir uçurum" olarak görmüștü. Sarton, bilimi sadece teknik bir meslek olarak önemsizleştiren düşünceden ziyade, bilim ve teknolojinin insanlığın en etkileyici aktiviteleri olarak görülmesini sağladı. Aynı zamanda bilim insanlarından da kendilerini beşerî bilimlerin bilimsel geleneklerini incelemeleri gerektiğini dile getirdi. Sarton, bilim tarihini "sadece bilim insani değil, aynı zamanda bir insan, bir vatandaş olduklarını da" anlamalarına yardımcı olan bilim ve beşerî bilimlerin bir sentezi olarak algıladı (Sarton, 2020, s. 27-28).

On beş kitabın ve üç yüzden fazla makalenin yazarı olan Sarton'ın diğer önemli eserleri arasında; Antik bilimden ve Yunanistan'ın Altın Çağı'ndan Helenistik döneme kadar uzanan süreci anlattığı derslerinin yeniden bir incelenmesi olan iki ciltlik Bilim Tarihi (A History of Science. Ancient Science through the Golden Age of Greece, Cambridge: Harvard University Press, 1952; A History of Science. Hellenistic Science and Culture in the last Three Cen- turies B.C., Cambridge: Harvard University Press, 1959); ikinci bir bibliyografi olan Bilim Tarihi Rehberi (A Guide to the History of Science, Waltham. Mass., Chronica Botanica, 1952); Rönesans Döneminde Antik ve Ortaçă̆ Biliminin Değeri (Appreciation of Ancient and Medieval Science during the Renaissance (1450-1600), Philadelphia: University of Pennsylvania Press, 1955) ve Bilim Tarihi ve Yeni Hümanizma (The History of Science and the New Humanism, Bloomington: Indiana University Press, 1962) gibi eserleri yer alır. Onun en meşhur eseri Introduction to the History of Science'dır (Baltimore: Williams \& Wilkins, 1927-48).

\section{DIŞSALCI YAKLAŞIM}

Günümüzde bu bakış açısı eleştirilmiş ve bilimin gelişiminin sadece içsel olarak değerlendirilmesiyle anlaşılamayacağı iddia edilmiştir. Dışsalcı bakış açısı olarak tanımlanan bu görüșe göre bilim tarihi yaklaşımı daha geniş tutulmalıdır. Anlayış olarak içselciliğin tersidir. Ekonomik, siyasi, toplumsal koşullar, teknik hatta politik ortamlar bilim üretimini belirler (Acot, 1999, s. 52). Araştırma alanı bilimsel araştırmanın mantığı değil, öncelikle bilim kurumudur. Bu yönelimde tarih, bilimsel çalışmaların içsel dinamiklerinin tespit edilmesi ve tarihsel olarak bu çalışmaların birbirleriyle karşılaştırılmasından öte, bu çalışmalar ile bu çalışmaların açığa çıktığı sosyal ve ekonomik koşulları ilişkilendiren daha geniş bir araştırmadır. Bilimsel bir araştırmanın ve bir bilim dalının dış tarihinin bulunması, o alandaki çalışma konularının, içerisinde etkinlikte bulunulan toplumun dinamiklerinden, sorunlarından etkilenerek seçildiği ve bu çalışmaların tarihinin ancak toplumun gelişme tarihi paralelinde yazılabileceği anlamına gelmektedir. Çünkü bilim, toplumdan özerk bir düşünsel adacık olmadığ gibi, bilakis toplum denilen ilişkiler ağının bir parçasıdır. İçselci anlayışın temelleri Comte'un Pozitivizmine dayanmaktaydı. Ancak klasik pozitivizm eleştirildikten sonra klasik pozitivizmin bilimsellik ölçütleri olan gözlem ve deneyi aynen benimsemekle birlikte, bunlara ek olarak dil ve mantık kurallarını da ölçüt olarak kabul eden ve klasik pozitivizmin devamı olan yeni pozitivizm düşüncesi karşımıza çıkar. Yeni pozitivistler bütün dikkatlerini önermelerin anlamı üzerine yoğunlaştırmışlardır. Buna göre önermelerin anlamı, doğrulanabilme yöntemleriyle eşdeğerdir. Felsefe tarihine doğrulanabilme ilkesi olarak geçen bu belirlemeye göre, bir önermenin doğrulanabilmesi demek, doğru olup olmadığına gözlem, deney, dil veya mantık kurallarına dayanarak karar vermek demektir. Eğer bu işlem gözlem ve deney yoluyla gerçekleşirse, o önerme ampirik, dil ve mantık kuralları aracılığıyla gerçekleşirse, analitik demektir. Yine bu felsefeye göre yalnızca bilimin önermeleri anlamlıdır (Grünberg, 1985, s. 33-34).

Bilimin bir dilinin ve mantığının olduğunu savunan mantıkçı pozitivizmin dil ile ilgili yaklaşımını bu dönem- 
de radikal bir biçimde ișleyen düșünürler de olmuștur. Bu düşünürlerin başında Ludwig Wittgenstein (1889-1951) gelir. Felsefeyi bir öğreti olarak değil, bir etkinlik olarak gören Wittgenstein, felsefenin görevinin önermelerin açık kılınması olduğunu ileri sürmektedir (Wittgenstein, 2018, s. 61). Ona göre dilin yanlış kullanımı sonucunda felsefe sorunları diye, aslında sözde sorunlar gerçekleşmektedir (Albrecht, 1986, s. 134-135).

Bilimlerde gözlemlenen gelişmelerin ortaya çıkardığ 1 bir diğer uyanış da hiçbir kuramın sonsuza kadar geçerli olmadığının kavranmasıdır. Bu özelliğinin aslında bilime sahip olduğu dinamizmi sağladığının öğrenilmesi epeyce geç bir dönemde olmuştur. Süreçte mantıkçı veya yeni pozitivizmin bilim üzerine oluşturduğu tasarruflar kuşkusuz önemli olmakla birlikte, bilimlerde ortaya çıkan gelişmeler hem bilim tanımını hem de felsefe tanımını değişime zorlamıştır. Nitekim pek çok konuda yakınlık taşıyormuş izlenimi yaratsa da bilimin ilkesinin doğrulama değil, yanlışlama olması gerektiği savıyla Karl R. Popper (1902-1994) konuya yeni bir yaklaşım getirmekten geri durmamıştır (Topdemir \& Unat, Bilim Tarihi ve Felsefesi, 2020, s. 234). Popper'a göre varsayımlar gözlem ve deneyle doğrulanamıyorsa, yenisiyle değiştirilir. Bilimin temel özelliği de yanlışlamadır. Popper'a göre, ulaşılan sonucun geçerliliğine ilişkin karar deney ışığında verilir; ve eğer karar olumlu ise, tekil sonuç benimsenir, doğrulanır ve dizge sınavı başarıyla geçmiş olur; buna karşılık karar olumsuz ise sonuçlar yanlışlanır; böylece sonuçların tümdengelimle türetildiği dizge de yanlışlanmış olur (Popper, 1998, s. 56-57).

Yanlışlamacı bilim anlayışı adı verilen Popper'ın yaklaşımı da eleştirilmiş ve bilimsel ilerlemenin gerçekleştiği kuram değișimleri sürecini dikkate alan Thomas Kuhn, her kuramın kendi tarihsel koşulları bağlamında dikkate alınmasının yeni bilim felsefesi ve tarihi anlayışının belirleyici kuralı olması gerektiğini ileri sürmüştür. Kuhn, yalnızca basit bir kronoloji ve söylev kümesi olarak görülmediği takdirde, her türlü söylemi barındıran tarihin, mevcut bilim kavrayışını oluşturduğu gibi, aynı zamanda güncel ve yerleşik bilim kavrayışının değiştirilmesinde de köklü dönüşüme yol açabileceğini belirtmektedir (Topdemir \& Unat, Bilim Tarihi ve Felsefesi, 2020, s. 235).

Khun meşhur eseri Bilimsel Devrimlerin Yapısı adlı eserinin Giriş kısmında şu sözlere yer verir: "Eğer bu zamanı geçmiş inançlara efsane denilecekse, o zaman bugün bilimsel olduğu kabul edilen bilgi türünün dayandığı yöntemlerle ve mantıkla da aynı şekilde efsaneler üreteceği açıktır. Yok eğer bunlara bilim denilecekse, o zaman bilim, bugün sahip olduklarımızla hiç de bağdaşmayan inanç topluluklarını kapsamış oluyor." (Kuhn, 2006, s. 73).

Bu bakış açısıyla düşüncelerini oluşturan Kuhn, bilimsel gelişmeyi kendince belirlediği bir kaç aşamaya bağlamıştır. 1) Kazanılmış bir ya da daha fazla bilimsel başarı üzerine sağlam olarak oturtulmuş araştırma olarak "olağan bilim" aşaması. Bu aşama yenilikten daha çok, kapalı ve uzmanlaşmış araştırma yapılabilen, aynı zamanda bir bilim dalının gelişmişliğinin göstergesidir. Aynı zamanda bilimsel araştırmaların egemen bir kuram çerçevesinde yürütüldüğü bir aşamadır. Olağan bilim evresine egemen olan kuramı paradigma olarak betimleyen Kuhn, zaman içerisinde paradigmanın çözemediği aykırı durumlarla karşılaşabildiğini ve çeşitli çözüm denemelerinde bulunulduğunu, ancak bazen her şeye karşın istenen çözümün gerçekleşmeyerek paradigmanın iflas ettiğini savunmaktadır. Bu sürecin nasıl gerçekleştiğini de betimleyen Kuhn, sürecin birinci adımını paradigmanın belirsizleşmesi ve bunun ardından olağan bilim kurallarının gevşemesi olarak belirlemektedir. 2) İkinci adım ise üç şekilde sonuçlanabilir: i) Sonunun geldiği düşünülen paradigma bunalım yaratan sorunu çözebilir; ii) Bunalım yaratan sorun direnmeye devam edebilir; iii) Bunalım yeni bir paradigma adayının ortaya çıkması ve bunun kabulüne ilişkin son bir mücadele ile sona erer. 3) Son aşama bir devrimdir ve devrimler geleneğe bağlı olan bilim etkinliğinin gelenek yıkan tamamlayıcılarıdır. Böylece bir paradigmadan diğerine geçerek bilimsel ilerleme gerçekleşmiş olur. Kuhn'un en önemli iddiası ise bu sürecin birikimle gerçekleşmediğini israrla vurgulamasidir (Topdemir \& Unat, Bilim Tarihi ve Felsefesi, 2020, s. 235).

Khun'un farklı düşüncesi bilim tarihine bakmanın güçlü ve yeni yollarını göstermiş ve dönüm noktası olmuştur (Iliffe, 2016, s. 88). Bu anlayışa göre bilimin gelişiminde epistemolojik kopukluklar vardır. Bu kopukluklar bilimsel devrimleri oluşturur. Bilim bu bağlamda bir etkinliktir ve tarihsel koşullarda gerçekleşir. Öyleyse bilimin gelişimini anlayabilmek için tarihsel süreçlere ve bu tarihsel süreçler içerisinde ortaya çıkan ve dönemin paradigmalarını savunan bilim topluluklarını incelemek gerekir.

Khun kendi zamanına kadar bilim tarihinde iki farklı gelenek olduğundan bahseder. 1) Condorcet, Comte ve Sarton geleneği. Bu gelenek bilimsel ilerlemeyi insanlığın boş inançlara karşı zaferi olarak ve bilimsel ilerlemeyi insanlığın en yüce faaliyeti olarak görür. 2) Bilim tarihini pedagojik amaçlarla ele alanlar. Bu gelenek ise ne genel bir bağlam ne de dışsal ve içsel anlayışı gözetirler (Khun, 1994, s. 187-188). Khun'a göre her iki gelenek de yetersizdir. Bilim tarihi alışılagelmişin dışında okunmalıdır. Zira tarih sadece bir zaman dizini deposu değildir. Ona göre art arda gelen teoriler birbirini içermez. Dolayısıyla her biri bağımsız bir şekilde ele alınmalıdır. Bu bağlamda her teori (ya da paradigma) kendi dönemi içerisinde tutarl1dır. Bilim tarihine de bu anlayış çerçevesinde yaklaşılmalıdır (Salgar, 2015, s. 227).

Kuhn'un bu düşüncesinin önemli yönü, egemen olan felsefi geleneği ve bilim felsefesini, bilim tarihiyle karşı karşıya getirmesidir. Bu konuyu Topdemir şöyle ifade eder:

“Özellikle yüzyılın başında akademik bir disiplin 
haline gelmiş olan bilim tarihi araştırmalarından edindikleri verilere dayanarak, bilimi felsefi yönden ele almaya çalışan filozoflar, pratikte etkinliğini sürdüren bilimin hem geçmişte hem de şimdi, tarihsel kaynaklarda belirtilen nitelikleri, en azından kısmen, taşımadı̆̆ı sonucuna ulaşmışlardı. Bu belirlemenin olumlu veya olumsuz yönde çözümlenebilmesi için, bilim felsefesinin bilim tarihinin verilerine tarihin hiçbir döneminde duyulmadiğı ölçüde gereksinimi olduğu ortaya çıkmıştır. Kısa süre içerisinde bu gelişmeyi görmüş olan Kuhn, Bilimsel Devrimlerin Yapısı adlı kitabında bilim tarihi ve bilim felsefesi arasındaki yüzleşmeyi gerçekleştirme yoluna gitmiştir." (Topdemir, 2002, s. 46).

Bilim tarihinin genel olarak Kuhn'un öngördüğü yaklaşıma benzer şekilde ilerlediği söylenebilir. Ancak olağan bilimin adeta bir cemaat kimliği taşıdığı iddiası tartışılır. Bilim toplulukları kapalı bir cemaatten daha fazla özgür düşünceye sahip olmalılar ki yeni bir kuram seçimine doğru gidiş başlayabilsin. Öyleyse bilim Khun'un iddia ettiği gibi dogmatik bir yapıya sahip değildir. Nitekim bu iddia pek çok bilim felsefecisince kabul edilmemiştir (Topdemir, 2002, s. 59).

Topdemir, Khun'un özellikle bilim tarihi anlayışını şu sözlerle eleştirir:

"Diğer taraftan, Kuhn'un belirlediği olağan bilim, devrim, olağan bilim şeklindeki dönemlemeleri astronomiye uygun düşmektedir, ancak örneğin biyoloji ya da optiğe denk düşmemektedir. Bilim tarihi her bilimsel alanda, dominant tek kurama dayanarak ilerleyen bir dominant kuramlar zincirinden ibaret olduğu savını desteklememektedir. Optikte birden fazla kurama dayalı bir ilerleme söz konusu olmaktadır. Bu anlamda Kuhn ya da diğer bilim felsefecileri bilime ilişkin temel öneme sahip problemleri dile getirmişlerdir. Bilimin doğasıyla ilgili derin kavrayışlarda bulunmuşlardır. Ancak hiçbirinin bilimin ya da bilimsel serüvenin özünü tam olarak yansitacak kanitlara sahip olmadikları böylece açı̆̆a çıkmaktadır.” (Topdemir, 2002, s. 60).

\section{GÜNÜMÜZDE BILIM TARIHINE FARKLI YAKLAŞIMLAR}

Günümüzde bilim tarihi en önemli araştırma alanlarından birisidir. Ancak Sarton'ın tanımladığı pozitivist yöntem dişında bu disiplini ve disiplindeki araştırmaları yönlendiren değişik yöntemler ve bakış açıları da ortaya atılmıştır. Örneğin Sarton'dan önce William Whewell Comte'çu kurama karşı olan yazılarında bilim insanı merkezli bir tarih anlayışına yönelerek bilimin rafine yöntemlerinin yaratılması düşünesine odaklanmıştı (Iliffe, 2016, s. 36-37). Yine George Clark, bazı eserlerinde bilimin gelişimini ekonomiyle ilişkilendirmişti (Iliffe, 2016, s. 58). Ne var ki Sarton alanı tanımladıktan sonra onun görüşü etkili oldu. Günümüzde Sarton ekolüne en ciddi eleştiri Thomas Khun tarafından yapılmıştır. Khun bilimin gelişiminin tarihsel ve kültürel arka planına odaklandı ve ilerlemenin paradigmaların devrimsel değişimiyle olduğunu iddia etti. Ona göre Sarton ve pozitivistler bilimin içsel dinamiklerini ele alıyorlar ancak bilimin gelişiminden sorumlu olan dişsal etkileri yok sayıyorlardı. Bilimin gelişimi, ekonomik, kültürel, sosyal gelişime bağlı olarak yeniden yorumlanmalıydı. 1960'lı yıllardan sonra bazı bilim felsefecileri Khun'a itirazlarını dile getirdiler. Buna göre Khun bir kuramın başka bir kuram karşısında tercih edilişinde yeterli bir zemin sunamıyor ve bir çeşit rölativizme düşüyordu (Iliffe, 2016, s. 91). Ancak Khun'un ileri sürdüğü bilimin sosyal tarihi anlayışı yine de varlığını sürdürdü ve yeni nesil araştırmacılar, bilimin sosyal tarihine yönelmeye başladılar. Bilimin sosyal tarihi araştırmalarına yönelen Bob Young 1970'li yıllarda yazdığı yazılarında bilimin tarihinin kavramsal ve sosyal, çok farklı faktörler tarafından belirlendiğini kabul eden ve günümüz bilim tarihi araştırmacılarının da temelini teşkil eden, evrensel bir tavır takınmanın daha doğru olacağını iddia etti (Iliffe, 2016, s. 128-129).

\section{SONUÇ}

Bilim bugünkü seviyesine, birçok bilim insanı sayesinde erişmiştir. Bilim insanını toplum yetiştirse de bilim insanı o toplumu daha ileriye götürmüştür. Bilimin gelişiminde toplumların etkisi olsa da bilimin çeşitli bölümlerinde yapılan keşiflerin büyük bir kısmının birbirine dayanarak ortaya çıktığını unutmamak gerekir. Zira herhangi bir keşfin ortaya çıkması için gerekli temel bilginin hazırlanmıș olması gerekir (Sayılı, 2010, s. 82-83).

Bilim tarihinin sınırları oldukça geniştir. Bilim tahine, tarih disiplini ve yöntemi çerçevesinde bilimin gelişiminin incelenmesi olarak bakarsak, bilimsel gelişim dönemleri, bilim insanlarının bilime katkıları, toplumların bilime katkıları, bilimsel düşüncenin gelişimi gibi konular bilim tarihinin konuları arasına girer. Yöntemsel olarak, tarihsel yöntemi kullanan, bilimi araştırması bakımından bilimsel yönteme dayanan, bilimin toplumsal gelişimini, dönemlerini irdelemesi açısından toplumsal işlevi olan, bilim adamlarının katkılarını ele alması açısından belli ölçüde bilim sosyolojisini kullanan, bilimsel düşüncenin gelişimini ele alması bakımından da felsefeye ihtiyaç duyan bir alan olarak ortaya çıkar. Bu bağlamda bilim tarihi, felsefi çözümlemelere dayanan, bilginin sosyolojik ve psikolojik süreçlerini ele alan, bunu yaparken de tarih yöntemini kullanan sınırları geniş bir disiplindir (Unat, 2015, s. 100).

Özellikle Khun'dan sonra bilimin gelişiminin sadece iç problemlerden etkilenmediği, dış faktörlerin de dikkate alınması gerektiği düşüncesi bilim tarihi çalışmalarına yeni bir boyut kazandırmıştır. Zira bilim günümüzde hem toplumu etkileyen hem de toplumsal problemlerden etkilenen bir yapıdır (Ural, 2016, s. 12). 
Bilim tarihi yeni bir disiplindir. Ancak kapsamı oldukça geniştir. Bilim sanıldığının aksine Rönesans'tan sonra ortaya çıkmamıştır. İnsanlığın ortak malıdır. Kökleri ilkel toplumlara kadar uzanmaktadır. Bilimi anlamak için bilimin bilim dışı düşünce biçimleri ile ilişkisinin de bilinmesi gerekir. Bu bağlamda bilim tarihi, mitoloji, din, sanat, felsefe, metafizik, din gibi konulara da yer vermek durumundadır (Yıldırım, 2020, s. 14).

\section{KAYNAKÇA}

Acot, P. (1999). Bilim Tarihi. (N. Acar, Çev.) Ankara: Dost Yayınları.

Albrecht, E. (1986, 1). Felsefe Eleştirileri Mantıksal Olguculuğun ve Çözümsel Felsefenin Kaynağı Ludwig Wittgenstein (Oğuz Özügül, Çev.). Felsefe Dergisi.

Comte, A. (2015). Pozitif Bilim Dersleri ve Pozitif Anlayış Üzerine Konuşma. (E. Ataçay, Çev.) Ankara: Bilge Su Yayınları.

Çalışkan, S. (2004). Türkiye'de Bilim Tarihi Sahasında Illk Doktora Tezi: Aydın Sayılı “Observatory in Islam”. Türkiye Araştırmaları Literatür Dergisi, 2(4), 701-720.

Dosay, M., \& Demir, R. (1995). Bilim Tarihinde Metin Çalışmalarının Önemi. Felsefe Dünyası(17), 60-70.

Fazlıoğlu, İ. (2004). İki Ucu Müphem Bir Köprü: 'Bilim' ile 'Tarih” ya da 'Bilim Tarihi'. Türkiye Araştırmaları Literatür Dergisi, 2(4).

Grünberg, T. (1985). Neopozitivizmin Bilim Anlayışının Eleştirisi. Bilim Kavramı Sempozyumu Bildirileri (s. 33-41). Ankara: Ankara Üniversitesi.

Iliffe, R. (2016). Bir Disiplinin Gelişim Hikâyesi, Bilim Tarihi. (M. D. Gökdoğan, Dü., S. Beşkardeşler, T. T. Gözütok, L. Günay, S. Kaygın, T. Uymaz, \& B. C. Serdar, Çev.) İstanbul: Lotus Yayın Grubu.

Kaçar, M. (2004). "Türk Bilim Tarihi Kurumu (TBTK) ve Bilim Tarihi Çalışmalarındaki Yeri”. Türkiye Araştırmaları Literatür Dergisi, 2(4), 581-593.

Kahya, E. (2009). Bilim Tarihinde Temel Yaklaşımlar ve Eğilimler: Bilim Teorileri. B. Arda, E. Kahya, \& T. Gül içinde, Bilim Etiği ve Bilim Tarihi. Ankara: Ankara Üniversitesi, Sağlık Bilimleri Enstitüsü.

Kâhya, E., Gökdoğan, M., Demir, R., Topdemir, H., \& Unat, Y. (2003). Türkiye'de Bilim Tarihi Araştırmalarının Dünü ve Bugünü, Ankara Üniversitesi, Dil ve Tarih-Coğrafya Fakültesi, Bilim Tarihi Anabilim Dalında Yapılan Çalışmalar. Ankara: Ankara Üniversitesi, DTCF Yayınları.

Kazancıgil, A. (1993). Aydın Sayılı́nın Yayınları. Bilim Tarihi(21), 20-26.

Khun, T. (1994). Asal Gerilim. (Y. Şahan, Çev.) İstanbul: Kabalcı Yayınevi.

Kuhn, T. S. (2006). Bilimsel Devrimlerin Yapısı (9.Baskı b.). (N. Kuyaş, Çev.) İstanbul: Kırmızı Yayınları.

Popper, K. R. (1998). Bilimsel Araştırmanın Mantığı. (illknur Aka \& İbrahim Turan, Çev.) İstanbul: Yapı Kredi Yayınları.

Salgar, E. (2015). Ilerleme Kavramı ve Bilimdeki Yansımaları. İstanbul: Hiperlink.

Sarton, G. (1924). The new humanism. Isis, 6 (1).

Sarton, G. (1927-1948). Introduction to the History of Science
(Cilt 1). Baltimore: Williams \& Wilkins.

Sarton, G. (1952). Auguste Comte, Historian of Science: With a Short Digression on Clotilde de Vaux and Harriet Taylor. Osiris, 10, 328-357.

Sarton, G. (1957). The Study of the History of Science. New York: Dover Publications.

Sarton, G. (2020). Bilim Tarihi. G. Sarton içinde, Bilim Tarihi Araştırmalarında Yöntem (R. Demir, Çev., s. 46-63). Muhayyel Yayınevi.

Sarton, G. (2020). Bilim Tarihi Araştırmalarında Yöntem. İstanbul: Muhayyel.

Sayılı, A. (1996). George Sarton ve Bilim Tarihi (Çev. M. Dosay, R. Duran). Erdem, Aydın Sayılı Özel Sayısı-1, 9 (25), 117-153.

Sayılı, A. (2010). Hayatta En Hakiki Mürşit ilimdir. (R. Demir, \& İ. Kalaycıogulları, Dü) Ankara: Atatürk Kültür Merkezi.

Tekeli, S., Kâhya, E., Melek, D., Demir, R., Topdemir, H., Unat, Y., Kalaycıoğulları, İ. (2021). Bilim Tarihine Giriş (11 b.). Ankara: NOBEL.

Topdemir, H. G. (2002). Kuhn ve Bilimsel Devrimlerin Yapısı Üzerine Bir Değerlendirme. Felsefe Dünyası, 2(36), 45-62.

Topdemir, H. G. (2016). Bilim Tarihi Araştırmalarının Felsefi ve Sosyolojik Yansımaları. Ömer Bozkurt (Ed.), Bilim Tarihi ve Felsefesi, Tarih ve Problemler. Mardin: Mardin Artuklu Üniversitesi Yayınları.

Topdemir, H. G. (2018). Bir Felsefe Disiplini Olarak Bilim Tarihi. 3. Uluslararası Felsefe, Eğitim, Sanat ve Bilim Tarihi Sempozyumu, Tam Metin Bildiriler Kitabı (s. 7-14). Giresun: Muğla Sıtkı Koçman Üniversitesi.

Topdemir, H. G., \& Unat, Y. (2020). Bilim Tarihi ve Felsefesi (2. Baskı b.). Ankara: Pegem A Yayınevi.

Unat, Y. (2005). Asâr-ı Bâkıye ve Yazııış Yöntemi. Osmanlı Bilim Araştırmaları, 7(1), 23-31.

Unat, Y. (2015). Astronomi Tarihi Çalışmaları ve Prof. Dr. Sevim Tekeli. Dört Öge(7), 3-17.

Unat, Y. (2015). Bilim Tarihi. A. Şimşek içinde, Tarih İçin Metodoloji (s. 99-102). Pegem Akademi.

Unat, Y. (2015). Ord. Prof. Aydın Sayılı (d. 1913 - ö. 1993). S. H. Bolay (Dü.) içinde, Tanzimat'tan Günümüze Türk Düşünürleri (Cilt 4-B, s. 2597-2616). Ankara: Nobel.

Unat, Y. (2017). Türk Bilim Tarihinde Bir Usta: Esin Kâhya. A. Şimşek, \& A. Şimşek (Dü.) içinde, Yaşayan Türk Tarihçileri (s. 277-286). Ankara: Pegem Akademi.

Ural, Ş. (2016). Bilim Tarihi (9 b.). İstanbul: Çantay Kitapevi.

Wittgenstein, L. (2018). Tractatus Logico-Philosophicus. İstanbul: Metis Yayınları.

Yıldırım, C. (2020). Bilim Tarihi (24 b.). İstanbul: Remzi Kitapevi. 